\title{
The Improvement of Democracy Trought Transparency and Its Limits
}

\section{Daniel Innerarity}

Ikerbasque Foundation of Science, University of Basque Country, Saint Sebastian, Spain

\author{
Email address: \\ dinner@ikerbasque.org
}

\section{To cite this article:}

Daniel Innerarity. The Improvement of Democracy Trought Transparency and Its Limits. International Journal of Philosophy. Vol. 5, No. 5, 2017, pp. 44-49. doi: 10.11648/j.jp. 20170505.11

Received: November 8, 2017; Accepted: November 21, 2017; Published: December 25, 2017

\begin{abstract}
Contemporary democracies have been configured as observation societies, which is revealed by the meteoric rise of the demand for transparency. This article examines the limits of transparency and its side effects as well as the disadvantages of a purely ocular conception of democracy. It proposes balancing the obligations for transparency with other democratic values that should be afforded equal weight.
\end{abstract}

Keywords: Tranparency, Publicity, Democracy

\section{The Observation Society}

A "monitored democracy" is that form of democracy in which citizens have multiple ways in which to observe and evaluate their governments. This possibility ranges from the traditional forms of parliamentary and judicial control to the growing role of regulatory agencies or social networks that ensure that everything that happens is an object of observation and public debate. The demand for transparency stems from the Enlightenment principle according to which the democratic life should be developed, in Rousseau's expression, "under the public eye" [1]. Since then, societies have evolved significantly and even though the problems they confront and our systems of government have become more complex, the demands for publicity have not decreased, quite the contrary.

The reason for this demand for transparency is found within the very evolution of society, by virtue of which the authorities are made more vulnerable and dependent [2]. Communication and information technologies make possible a type of democratic surveillance that was unthinkable at times of asymmetric information. The old power mechanisms do not function in a society in which citizens live in the same informational environment as those who govern them [3]. Every society that is democratized generates a corresponding public space, in other words, it is transformed into an environment where new rules of observation, surveillance, desire for transparency, debate and control are in force.
We live in what I like to call an "observation society" which consists of the unstoppable incursion of societies into the political scene. Political systems, from the domestic realm to the global space, are increasingly publically monitored. Let us think, for example, about what has taken place with international politics, how it has recently been transformed after benefitting for a long time from the privilege of ignorance. States could take the liberty of doing almost anything when what they were doing was barely known. The Soviet army met with less resistance when they attacked Budapest in 1956 that they did twelve years later in Prague; by then, European homes had televisions and the image of the deployed Warsaw Pact tanks helped forge the beginning of an international public opinion.

Globalization is also a space of public attention that noticeably reduces distances between witnesses and actors, between those who are responsible and spectators, between oneself and everyone else. In this way, new transnational communities of protest and solidarity are formed. These new actors, to the extent that they monitor and denounce, increasingly destabilize the authorities' ability to prevail in a coercive manner. An observing humanity participates and is acting directly in the debate that establishes world public spaces and acts in the name of universal legitimacy, in such a way that no state can ignore the gaze resting upon it.

As in other spheres of life, in politics, the fact of knowing you are being controlled improves our behavior or, at least, dissuades us from committing the errors that are born in 
secrecy and where there is no transparency. As Bentham stated, publicity guarantees integrity and loyalty to the general interest, at the same time as it constructs a "distrustful surveillance" [4] over those who govern. Our public spaces know many expressions of this tendency, which has come to be called "naming and shaming": the dissuasive power of condemnation, public exposition, denunciations and shame, which is not an all-embracing power but it often disciplines behaviors.

\section{The Disadvantages of Being Observed}

I would like to point out the limits to transparency and one of its possible side effects. Now that I have emphasized the importance of being controlled, I would like to point out the necessity of not being controlled, in other words, the impoverishment of political life when the principle of transparency is absolutized and we turn democracy into "politics broadcast live", which is worn out with constant and immediate surveillance. One of the effects derived from the extreme surveillance of political actors is that it leads them to overprotect their actions and their words. One example of this is the fact that many politicians, knowing that their smallest acts and declarations are examined and shared, tend to restrict their communication. Democracy today is more impoverished by speeches that say nothing than by the express concealment of information. Politicians should respond to the demand for truthfulness, of course, but also to the demand for intelligibility. A good deal of the people's dissatisfaction with politics stems not from politicians being untruthful but from them being so predictable and not saying anything at all.

The principle of transparency should not be absolutized because political life, even if to a small measure, requires spaces of discretion. Many other professions do as well of course, such as journalists, whose right to not reveal their sources is recognized, because otherwise they could not do their job effectively. They should not defend it as a privilege (generally absences, silences or news conferences without questions are unjustifiable) but as a space of reflexivity in order to better perform the job that citizens have the right to expect from their representatives.

We should not let ourselves be seduced by the idea that we are facing a world of information that is available, transparent and without secrets. This is necessary because, in the first place, we know that certain successful negotiations from the past would not have been produced if they would have been retransmitted live. There is something we could call the diplomatic benefits of intransparency. Of course the secrecy of many traditional procedures are destined to disappear and those who participate in diplomatic processes from this point forward must be conscious that almost everything will end up being known. But it is also true that the demand for total transparency could paralyze public action on more than a few occasions. There are compromises that cannot be reached in the light of day and with stenographers, both of which tend to provoke actors to radicalize their positions and in no ways makes politics a place of sincerity.

A recent example of this is the demand presented by Italy's Five Star Movement in 2013 that its negotiations with the Partito Democratico to form a government be retransmitted by streaming. We all understood at that moment that such a demand meant that there would be no agreement. I do not believe it an exaggeration to formulate the principle that a retransmitted meeting is an un-deliberative meeting. Discrete commissions probably have much greater deliberative quality than the weekly rituals of plenary sessions to control the government. In spite of certain precipitous celebrations of an imminent world without duplicity or areas of shadow, the distinction between being on and off stage continues to be necessary for politics. Additionally: by pressuring for transparency and immediacy, the media provokes the behindthe-scenes politics that they then criticize. There will always be a second space in which the agreements that are impossible in a space continuously exposed to everyone's scrutiny can be hatched. For that second level the principle of popular legitimacy is also valid, of course, but here the relationship between representatives and those represented will be more for delegation and accountability than for immediate exposure.

We must convert the principle of transparency into a central demand for governmental action in a democratic society, without losing sight of the fact that, like any principle in politics, it should be balanced with other priorities. Furthermore, its possible negative effects must be taken into consideration. As our political systems fight against unjustified opacity, we have also noted that those same control mechanisms tend to transmit excessive distrust and a fundamentally negative vision of politics [5]. Some of the rules of transparency and accountability can damage rather than reinforce confidence, to the extent that-in contrast with its declared purpose-they feed a culture of suspicion that increases public distrust.

At the same time, there are a series of strategies to produce intransparency through transparency, which Luhmann explained with particular subtlety [6]. "Being under the popular eye can be an astute strategy on the part of the leader or the communication experts to decrease the people's control of the leader's power if some previsions that have nothing to do with his public appearance are not taken" [7]. Transparency is only a principle that improves our democratic life if it is not enshrined while ignoring the selfinterest that can be made of it and its consequences throughout the democratic society, which is also made up of other values, some of which are not very compatible with absolutized transparency.

\section{Better Publicity Than Transparency}

Transparency is, without a doubt, one of the principal democratic values, allowing citizens to control the activity of 
their elected officials, verify respect for legal procedures, understand decision-making processes and trust political institutions. That is why it is not strange that it has exercised a power of fascination that sometimes makes it difficult to analyze its meaning, reflect on its content and its limits or undesired consequences. The principle of transparency has such an indisputable status that it can take the luxury of being indistinct and vague. We should not consider transparency as the only norm of our action on social reality, even admitting that it stems from a legitimate desire to democratize power. In addition to limits, transparency can have negative consequences. More than a few scholars have noted that the internet can become an instrument of opacity: the increase in the amount of data provided to citizens complicates their surveillance [8]. How can citizens successfully carry out this task of control over the authorities?

For this reason, I prefer to talk about publicity and justification, which are more demanding principles than the principle of transparency. While transparency expects continuous visibility, publicity is by definition limited and delimited. Let us consider whether perhaps harassing some of our representatives at their homes or workplaces, which takes legitimate protest to private spaces, leads to great confusion about the distinction between the public and the private; we have sown an idea of transparency that suggests a continuous visibility over people rather than a principle of publicity that is essentially limited to the acts that make political sense and in the spaces of public domain, thus allowing areas of intimacy and a private or even secret life.

On the other hand, while transparency tends to settle for data being made available, publicity demands that this data be configured as information that is intelligible to citizens. Transparency does not presume real access to information. In contrast, publicity means that the information is truly disseminated, that it is taken into account and that it participates in the formation of points of view. Because it is illusory to think that as long as the data is public, truth will reign in politics, the authorities will open up and citizens will understand what is really going on. In addition to access to public data, there is the question of meaning. Placing large quantities of data and documents on the web is not enough to make public action more intelligible: it must be interpreted, the conditions under which it has been produced must be understood, without forgetting that this type of information generally does not account for more than a slice of reality. Transparency is a necessary condition of publicity, but it does not guarantee it. This is the reason that there can be potential availability of information but a lack of true publicity for many different reasons: because the work of the mediators (such as institutions, the means of communication, the labor unions and political parties) is not effective or because of limitations of a cognitive order [9].

It is a delusion to think that we can control the public space without institutions that mediate, channel and represent public opinion and the general interest. What is occurring nowadays is that the disrepute of some of these mediations has seduced us with the idea that democratization means disintermediating. Some people-with a logic similar to that used by the neoliberals to dismantle the public space in benefit of a transparent market-insist on criticizing our imperfect democracies based on the model of a direct democracy, articulated by spontaneous social movements, from the free play of the online community and beyond the limitations of representative democracy. The platitude that journalists, governments, parliaments and politicians are dispensable has been established, when what they truly are is improvable.

I am convinced that we are mistaken with this approach, which does not mean that the mediation provided by those professionals is always satisfactory. In a contemporary democracy, we citizens would not be able to clarify what is taking place, much less challenge the degree to which it strikes us as deserving of reproach without the mediation, among others, of politicians and journalists, to whom we owe, in spite of their many errors, some of our best democratic conquests.

Advanced societies rightly claim that there is greater and easier access to information. But an abundance of data does not guarantee democratic surveillance; that requires, additionally, mobilizing communities of interpreters capable of giving context, meaning and critical assessment. Separating the essential from the anecdotal, analyzing and placing the data in appropriate perspective demands mediators who have the time and the cognitive ability. The political parties (another example of an institution that needs to be renovated) are an essential instrument for reducing that complexity. Journalists are also inevitable in the task of interpreting reality; their job is not going to be superfluous in the age of the internet, quite the contrary. Journalists are called upon to play an important role in this cognitive mediation to interest the people, animate public debate and decipher the complexity of the world [10]. But I am defending the cognitive necessity of the political system and the means of communication, not their representatives who, like all of us, are also manifestly improvable.

\section{The Private Lives of Politicians}

We are witness to the increasing presence of politicians' private affairs in public opinion. This is due in part to the fact that public surveillance brings to light some aspects of the life of those who represent us that they would have preferred to keep secret. But this publicizing of that which is personal often stems from politicians themselves and their communications advisors, who offer up aspects of their personal life that they consider beneficial for their popularity and the electoral battle.

The politics of transparency and the intentional exposure of one's own personal life are modifying certain conventions regarding the separation between the public and the private, even in those countries that used to clearly distinguish the two spheres. In any case, this over-exposure of private life is 
bringing about a transformation in the logic of the game, which turns politicians into victims or beneficiaries depending on the particular situation. Among the causes of this transformation, we can note growing competition among the means of communication, a degree of de-ideologization and the personalization of campaigns or the development of internet. These are factors that clearly contribute to our understanding of some mechanisms without which this change in the limit of our collective attention would not have been possible. But there are reasons of a more structural nature that suggest that we are living in a time of expansion and generalization of the private that weighs on the public space and denaturalizes it. This tendency is going to persist and one of our principal challenges is determining how to confront it based, among other things, on new considerations about the relationship between the private and the public. It is not so much a question of protecting politicians' right to a private life but preserving the integrity of the democratic process.

One argument for limiting public use of politicians' private lives would come from the protection of an individual right, that allows each of us, politicians included, to prevent having activities that they want to protect from general scrutiny revealed, observed or exposed without their consent. It is not a bad argument, since those who govern also have a right to privacy, but it is weak since it does not take into account that we are not speaking about just any citizen. Competing for a public office is a free choice for the candidate, who should be conscious of the burdens it entails. Those who struggle for power must know that they cannot claim the right to privacy to the same extent as ordinary citizens. Greater power entails greater responsibility and therefore less freedom in which to hide. Those who exercise political power would like to enjoy being invisible in order to do what they wish they could do without suffering a public reprimand or censure [11].

But the argument that is focused on the protection of the private life of those who represent or govern us is insufficient, especially, because it does not center on the good that must be preserved. When it is a question of political representatives, it is the demands of democratic space that determines their rights and their particular obligations. Granting politicians an unlimited right to privacy would assure them excessive power of control over the public discourse, which would lower the quality of democratic debate. Politicians have a demand for responsibility that relativizes or diminishes their right to a private life. This demand would justify making public certain behaviors that are generally considered private (information about their physical or mental health if it could affect their abilities, their financial situation or even the economic situation of their family members that could create conflicts of interests or any circumstance that might condition their public behavior). The principle of democratic responsibility authorizes a certain degree of publicity about the private life of politicians, to the extent that information is considered necessary to evaluate their past, present or future capacity to assume a public function.

At the same time and for identical reasons (protecting the quality and responsibility of democratic life), there are good reasons to limit the publicizing of private life. When politicians' private lives are made public, it has very negative effects on political life. When revelations on private life dominate any other type of information, the general quality of public debate declines. There are many examples of this. For example, the Clinton-Lewinsky relationship marginalized the media's treatment of other questions like the new political proposals on social security, campaign finance, but especially the justification of the U.S. position on Iraq and the preparation for military intervention.

There is no doubt that certain sexual behaviors should be more publicized than they are. Sexual harassment is not a private matter. Behaviors that have a uniquely private character in principle, become a topic of legitimate investigation when they violate the law. However, with the exception of these concrete cases, excessive media coverage focused on politicians' private activities distracts our practices of democratic deliberation. The more attention that is focalized on the banal details of private life, the less we develop the capacity to assess the nuances of public life. Politicians' private lives act as a great distraction in profoundly depoliticized societies.

For that reason, when a media outlet questions whether it should or should not reveal a private behavior, the questions it should ask itself are: what effects would this have on the quality of our democratic life? Is it knowledge that citizens should have in order to evaluate the actions of their representatives? If it must be done, does the degree of publicity match its relevance?

When transparency is demanded, it is important not to forget that the powerful or the industries of transparency have ways in which to divulge information and images that produce the emotional reactions that are most favorable to them, in other words, provoking the intransparency that suits them. Taking politicians to the public stage does not eo ipso limit and control their power. The case of Berlusconi has been very illustrative in this regard: highlighting a leader's private life creates a spectacle that conceals the truly political considerations that should be in the public agenda. Berlusconi was permanently under the watchful eye of the media, but their intrusion on his life served, not to evaluate his political weaknesses, but to satisfy a certain hunger for scandals, which allowed us to overlook that which was truly important. As Michaël Foessel affirms, politicians entertain us with themselves so as not to have to talk about us [12].

Making the life of the politician visible may make political life invisible. Giving the people ocular power does not guarantee that we are going to look at that which is most important or what society needs to know. The ocular power of the people tends to focus more on the person of the leader than on his or her policies. The things that should be the object of public visibility are not as interesting for observers as other matters; we are more curious, for example, about how much a politician earns than about how much work is actually being done; there are personal behaviors that create 
more of a scandal than a scandalous decision would. This predominance of the personal is similar to our tendency to point a finger at a guilty party in order to visualize complex matters; "politicians" also satisfy this reduction of complexity by suggesting things are merely personal, converting the structural into something that can be assumed by a person. Between our personalization of leadership and our recourse to scapegoats, we lose sight of those complex structures that should be the object of our democratic surveillance.

\section{From the Power of the Word to the Power of Vision: Ocular Democracy}

Democracy is the power of the citizens. The question is how we understand this power, how it is exercised, what modalities of empowerment are put into play. The current apotheosis of transparency implies understanding citizen power, fundamentally, as a power of vision.

Every society establishes a regulation of the relationships of visibility. In traditional societies, one of the privileges of power is a privilege of active attention: seeing everyone without being able to be seen or without having to be seen. The emotion of many stories about emperors, popes or caliphs who disguised themselves in order to mix with the people and thus discover the state of public opinion is not due to the tensions of spy craft that they contain, but depends precisely on those fathers of the nation not being known. The great authorities of the past were recognized by their weapons, crowns, robes, insignia or musical fanfare, but barely by their faces. The king was never naked. For modern political careers, on the other hand, the key is in having $a$ privilege of passive attention: being seen by everyone without being able to see or without having to see. A contemporary emir no longer needs to camouflage himself; he can visit his territories every afternoon in order to be recognized, without the inconvenience of immediate contact with the people. This is possible courtesy of the means of communication, whose political relevance consists fundamentally of their being the current distributors of the relations of visibility. Nowadays an anecdote of an authority figure camouflaged among the people would be impossible. Power resides in the face and that is why the paraphernalia that used to accompany authorities has fallen into disuse; the abandonment of these signals is due more to their uselessness than to the modesty of those who have chosen to do without them.

Modern politics has turned previous privileges on their heads. The public that politicians address is anonymous, undefined. The people are now invisible and those who have authority have it because they have managed to acquire a position of visibility for the other; those who govern are not those who see but those who are seen. The ability to see and not be seen belongs now to those who are governed.

The best formulation of this new ocular democracy in the age of spectacle can be found in Jeffrey Edward Green's book, The Eyes of the People, in which he states that "the gaze rather than the decision ... [is] the critical ideal of popular power" [13]. The people as spectator would have a power that the elite do not: the power of unveiling, a type of negative power that imposes an ocular responsibility on the representatives, the weight of being observed. The spectators are thus situated in a position of equals with those who are seen. The masses enjoy the omnipotent invisibility that guards used to have, and they exercise the pressure of constant vigilance over the representatives. In this way, the people are understood as an impersonal and completely disinterested unit that inspects the game of politics from the outside by virtue of the principle of publicity. Participation is minimal but the contemplation is extensive. The anonymous mass of those who see only looks because they essentially do not take part in the game except to elect those who truly compete.

If in representative democracy the voice, discourse and ear were, respectively, the primary organ, function and sense, today the eye, the judging mirror and vision are central instead. In this way, the democracy of the internet has not broken, but continues the democracy of television; it is not the child of the discursive model of the agora but the videocratic model of the society of the visual means of information, which has replaced the voice with vision. Even though internet users interact and are not merely passive, their type of interaction is carried out in the assertive and apodictic style of images. Democratic dialogue has very little to do with the interchange of declarations on Twitter. All of this presupposes a decline in the politics of ideas and discursivity [14]. Mediation and discourse have come to an end and are now secondary categories in the empire of vision.

The demand for transparency is fundamental so people can be in a position to judge and control, but it can be limited to being a voyeuristic reward for a public that does nothing but watch. We are, as Bernard Manin defined it, in an "audience democracy" [15] and politics has become something that the citizenry contemplates from the outside. Citizens have stopped being participants and have become passive spectators.

The empire of the visual impoverishes the level of political discourse. The public feels visually drawn to themes or perspectives about the themes that strike them as the most attractive, which do not always coincide with the true political issues or the depths of the matter, which frequently remains beyond the spectacle. One thing may conceal the other. In this way, not even the function of democratic surveillance can be fully exercised, since the spectacularization of political life hinders the perception of everything that does not fit into the category of spectacularity, things that are not very attractive to the citizen-spectator, anything that does not impress or is not personal, issues that do not stir rage or envy or indignation, everything that is normal, banal, structural or complex. 
Being "under the public eye", as Rousseau demanded, can lead to a "politics of passivity" [16], to a theatricalization in which there is more entertainment than control, more "politainment" than political judgment. For opinions to be public, it does not suffice that they be publicly expressed; they must form a part of "public affairs", the res publica, and the judgment of what belongs is something that citizens carry out freely when they participate in the formation of their will and judgment as citizens, not as simple observers [17]. In order to forge a political will, one must do more than look; one must also participate, speak, protest. In an ocular democracy, the people can feel less encouraged to participate or decide as a sovereign precisely because they are busy continuously supervising their representatives. The spectacle is enough for them, exercising the negative sovereignty that limits the power of their representatives. In this way, transparency will be revealed as a strategy of regeneration that does not rise to the level of what is promised and that is, at times, even a true democratic distraction.

\section{Conclusion}

In recent years, the concept of transparency has had a meteoric rise in our democratic societies. The observation of authorities is presented as a great instrument of citizen control and democratic regeneration. However, as with all political principles, transparency must be promoted and balanced with other principles. It would be best if our enthusiasm for transparency did not conceal the difficulties of truly exercising it, its disadvantages and possible side effects, as well as the game of concealment it can promote. In addition to observing, citizens must have other abilities that are as essential for democracy. If we pay attention to all the variables that intervene in a democratic society, we can affirm that transparency is a value that should be promoted in its just measure, which is as necessary as it is limited, that a democracy requires transparency but does not tolerate it in excess, nor can transparency be declared democracy's sole principle. Our ocular democracies are articulated around the observation of the struggle that its elites unleash, and within the observation of that spectacle, we find both the strength of its control and the limitations of transparency.

\section{References}

[1] Rousseau, Jean Jacques (1969) "Considérations sur le Gouvernement de Pologne”, in Euvres complètes III, Paris: Gallimard, 970-971.

[2] Rosanvallon, Pierre (2008), La légitimité démocratique. Impartialité, réflexivité, proximité, Paris: Seuil, 61.

[3] Giddens, Anthony (2002), A Runaway World, Profile: London.

[4] Bentham, Jeremy (1999), "Of Publicity”, in Michael James / Cyprian Blamires (eds.), The Collected Works of Jeremy Bentham, Political Tactics, Oxford University Press.

[5] Behn, Robert (2001), Rethinking Democratic Accountability, Washington: Brookings.

[6] Luhmann, Niklas (1995), Die Realität der Massenmedien, Opladen: Westdeutscher.

[7] Urbinati, Nadia (2014), Democracy Disfigured. Opinion, Truth, and the People, Harvard University Press, 213.

[8] Fung, Archon / Graham, Mary / Weil, David (2007), Full Disclosure, the Perils and Promise of Transparency, Cambridge University Press.

[9] Naurin, Daniel (2006), “Transparency, Publicity, Accountability - The Missing Links", Swiss Political Science Review 12 (3), 91-92.

[10] Rosanvallon, Pierre (2008), La légitimité démocratique. Impartialité, réflexivité, proximité, Paris: Seuil, 342.

[11] Urbinati, Nadia (2013), Democrazia in diretta. Le nuove sfide alla rappresentanza, Milano: Feltrinelli, 169.

[12] Foessel, Michaël (2008), La privation de l'intime, Paris: Seuil.

[13] Green, Jeffrey Edward (2010), The Eyes of the People: Democracy in an Age of Spectatorship, Oxford University Press, 15.

[14] Urbinati, Nadia (2014), Democracy Disfigured. Opinion, Truth, and the People, Harvard University Press, 171, 85.

[15] Manin, Bernard (1997), The Principles of Representative Government, Cambridge University Press, 218.

[16] Urbinati, Nadia (2014), Democracy Disfigured. Opinion, Truth, and the People, Harvard University Press, 171.

[17] Sartori, Giavanni (1987), Theory of Democracy Revisited, 1. The Contemporary Debate, Chatham: Chatham House, 87. 